\begin{tabular}{l|l} 
dossier & THE PRESS \& PRESSURE: \\
a critical discourse analysis of the \\
promotion of "responsibility to \\
protect" or "sovereignty" narratives in \\
the on-going Syrian crisis
\end{tabular}

Copyright (c) 2015 SBPjor / Associação Brasileira de Pesquisadores em Jornalismo
MARKOS KOUNALAKIS

Stanford University, Califórnia, Estados Unidos

\begin{abstract}
The popular concept that journalism is a moderating check on an aggressive state - one that operates in a world dictated by Realism's demands for power and survival - is solace both for society and individual journalists who believe in the peaceful calling of the profession and the power of the Fourth Estate. But what happens when data and a discursive analysis of news organizations indicates that rather than favoring diplomatic solutions and peaceful resolutions, journalism is both fueling the flames of fear and fostering aggressive military postures that may favor confrontational nationalist rather that peaceful internationalist outcomes? This paper analyzes news and opinion production in both the Chinese and American press to conclude that in the case of the on-going conflict in Syria, the states themselves, while in conflict on the promotion of policies that reflect either the "Responsibility to Protect" (United States) or that of "Sovereignty" (China), are more aligned with diplomatic resolution than the press.
\end{abstract}

Keywords: Journalistic narratives. Discourse analysis. Chinese press. American press. Syria.

\title{
IMPRENSA E PRESSÃO: análise crítica do discurso de promoção das narrativas de "responsabilidade de proteger" ou "soberania" na crise Síria
}

RESUMO - O conceito popular de que o jornalismo é um freio em um estado agressivo - que opera em um mundo ditado pelas demandas do realismo por poder e sobrevivência - é um conforto tanto para a sociedade quanto para jornalistas, que acreditam em um chamado pacífico da profissão e no poder do quarto Estado. No entanto, o que acontece quando dados e uma análise discursiva de empresas jornalísticas indicam que em vez de favorecer soluções diplomáticas e resoluções pacíficas, o jornalismo está alimentando as chamas do medo e estimulando posturas militares agressivas, que podem favorecer resultados nacionalistas confrontadores e não aqueles internacionalistas pacíficos? Este artigo analisa notícias e textos opinativos na imprensa chinesa e americana para concluir que, no caso do conflito na Síria, os próprios estados, embora em conflito na promoção de políticas que reflitam tanto a noção de "Responsabilidade de Proteger" (EUA) quanto a "Soberania" (China), estão mais alinhados com a resolução diplomática do que com a imprensa.

Palavras-chave: Narrativas jornalísticas. Análise do discurso. Imprensa chinesa. Imprensa estadunidense. Síria. 


\section{LA PRENSA Y PRESIÓN: \\ un análisis crítico del discurso de la promoción de la "responsabilidad de proteger" o narrativas "soberanía" en la crisis siria en curso}

RESUMEN - La noción popular de que el periodismo es un freno en un estado agresivo - que opera en un mundo dictado por las exigencias del realismo por el poder y la supervivencia - es un consuelo para la sociedad y para los periodistas, que creen en una llamada pacífica de profesión y cuarto poder del Estado. Sin embargo, ¿qué sucede cuando los datos y un análisis discursivo de empresas periodísticas indican que en vez de favorecer soluciones diplomáticas y resoluciones pacíficas, el periodismo está alimentando las llamas del miedo y estimulando posturas militares agresivas, lo que puede favorecer a los resultados nacionalistas de confrontación y no los internacionalista pacífica? Este artículo analiza las noticias y artículos de opinión en la prensa china y americana a la conclusión de que, en el caso del conflicto en Siria, los propios Estados, a pesar de los conflictos en la promoción de políticas que reflejan tanto el concepto de "responsabilidad de proteger" (EE.UU.) y la "Soberanía" (China), están más en consonancia con la resolución diplomática que con la prensa.

Palabras clave: Periodismo. Ciberacontecimiento. Redes sociales. Crisis. Realidad social.

\section{INTRODUCTION}

In the ongoing Syrian crisis, media worldwide construct a discursive narrative for both their national and international audiences. Much of that narrative of the last two years focuses on the humanitarian concerns and suffering of the Syrian population. Newspapers are an important part of the wider global media ecology and they construct and promote policy preferences through their editorial choices and textual rendering of the Syrian crisis, both directly in their opinion pieces and indirectly in their more fact-based reported pieces. Those policy preferences may or may not align with the policy preferences of the state in which the media organ is published or produced, though media discourse is understood to have an effect on national policies and in international bodies (ROBINSON, 2001). This paper will look at this discourse and its construction by examining opinion pieces of popular English-language publications both in the United States and China to see how they manifest two specific policy concepts related to the Syrian crisis: The "Responsibility to Protect" (R2P as it is now known in western policy circles) and "Sovereignty." This paper further will consider levels of media-state alignment in the construction or advocacy of specific policy preferences. 


\section{THEORETICAL FRAMEWORK}

\subsection{R2P AND THE CONCEPT OF SOVEREIGNTY HAVE A LONG CONSTRUCTED HISTORY}

The concept of Sovereignty is an old and established one predating the nation-state, but becoming constitutive of the very concept of nation-state. International order is based on this mutually constituted concept and respect for the parameters of sovereignty during war and in peace, has withstood the test of time. Legal state sovereignty's roots are directly traceable to the Peace of Westphalia of 1648.

$\mathrm{R} 2 \mathrm{P}$, or, rather, the right of intervention and infringement on national sovereignty and interest, also has its legal roots in the $17^{\text {th }}$ century and can claim its pedigree in the three books by the Dutch jurist Hugo Grotius, De jure belli ac pacis libri tres (Grotius, 1751), a work that heralded the concept of a "just war." This idea has evolved over time and - through the many wars and interventions based on a "just war" principle - into our modern era. It has permutated in the humanitarian realm under the rubric and international legal norm of R2P.

R2P specifically, however, is a relatively newly articulated policy concept, established via policy adoption at the United Nations in 2001, though it has its precursors in historic actions (and inactions) by nation-states that have used humanitarian crises as the justification for overriding - or discarding outright - sovereign rights in the last three decades (EVANS; SAHNOUN, 2002).

Its recent evolution can be traced through the conflicts and crises that were no longer seemingly as remote as the seas of a distant shore, but were brought to our living rooms and breakfast tables via a graphically evolved and more sophisticated media than anyone at the time of Grotius could have imagined. Western newspapers used their opinion pages and their editorial imagery to express outrage at the inaction of states to intervene in bloody massacres and the western discourse of the time was sometimes in direct conflict with the policy preferences of their states. In Bosnia and Rwanda during the time of the George H.W. Bush and Bill Clinton administrations, the American media were harsh critics of both administrations' inaction in the face of what has in retrospect been broadly accepted and classified as "genocide" or "ethnic cleansing."

The newspapers and television coverage of the Rwandan genocide - and the international community's inaction during the most intensive and concentrated mass murder in history - raised 
the stakes for both world citizenry and media organizations as the question of "what can be done?" came to dominate the western humanitarian discourse.

Rwanda's remote and non-strategic location made foreign states' indifference feasible, but the molding of an international humanitarian intervention principle that would trump the concept of sovereignty was starting to develop as a result. The contravening narrative by popular media both exerted political pressure and may have had an effect in the eventual international intervention in Bosnia (WOOD; PEAKE, 1998). As a result of the conceptual refinement of R2P over the last few years and following not only the Rwandan and Bosnian events, but also on the heels of Somalia, Kosovo, Afghanistan, Iraq, and, most recently, Libya, a protocol and policy naturalization, with its own value constructions, has evolved.

These value constructions (legal rights and obligations, legitimacy, etc.) are mostly shared by both R2P and Sovereignty constructions, but the framing of those value variables varies widely, as this paper intends to highlight with the collected data. Both R2P and Sovereignty constructions rely, for example, on establishing legal norms and precedent for their respective defense, justification, and execution. This legal example is illustrated by examining where newspaper opinion pieces fall on an axis of principle advocacy (presented in the Findings section) as media opinion pieces advocate on a legal basis for the R2P or Sovereignty principle. Evaluating and analyzing this data makes a contemporary understanding of how media construct the current Syrian situation relevant.

\section{THEORY \& BENCHMARKS}

The theoretical framework in which this paper works with is an understanding that R2P today is a contested foreign policy practice with strategic import. It is invoked by states that attempt to implement it based on their perceived strategic national policy interests and that in strategically contested regions of the world where state interests conflict, the counter principle of Sovereignty is invoked to trump R2P by states with the conflicting interest.

This paper contends that the researched media enjoin in this conflict and construct a discourse that frames the issue as a struggle between the two policy principles and that they advocate 
for one or the other principle. Further, it is the goal of this paper not only to show that the researched media of this study advocate for a specific principle, but also for a specific policy action ranging from non-intervention to intervention.

In the course of analyzing this framed discourse, it is further a goal of this paper to intimate levels of alignment that the media framing has with the state policies of the nation in which national newspapers are published.

Understanding this constructed media discourse is important as key policy decisions are often informed to varying degrees by a catalyzing media power; a power which, at times, has the ability to provide an elite with the impetus to take difficult policy action or to rally popular support for costly policy decisions. Though it lies beyond the scope of this paper to conclude whether the media are seen as independent actors in this drama or as reproducing mouthpieces for a ruling elite or state, it is important to understand that to whatever degree or effect, the power that media effectively have is extant.

Discursively, what will be interpreted as being supportive of the sovereignty principle will be opinions that reinforce the primacy of independence, self-government, and non-intervention. Media discourse that constructs a positive discourse and advocates for the sovereignty principle, privileges state independence.

In R2P, the construction of the conditions for humanitarian intervention should argue that the state is not legitimate for multiple reasons including regime-type (e.g., non-democratic or dictatorial), security (inability to protect its people), or because it is engaged in crimes against humanity. Media discourse that constructs a positive discourse and advocates for R2P, privileges state intervention. The constructed argument will, in essence, amount to a "burning house" immediacy of action, requiring a neighbor to intervene and put the fire out, not only to save the house and those inside, but further, to prevent the fire from spreading and burning down the entire neighborhood.

\section{BACKGROUND}

In the winter and spring of 2012 , non-violent civilian protests in Syria were met with severe and violent responses by the state and its military. The violence escalated and was met by peaceful civilian resistance, at first, and then by low-grade, small weapons 
(no armored vehicles, RPGs, or air capabilities) armed resistance both against the military and the regime of President Bashir al-Assad.

Syria, long an ally of the USSR and - after the end of the Soviet Union - of Russia, was experiencing much of the same street protest activity (albeit not in the capital, Damascus) that previously had toppled the Qaddafi regime in Libya and the Mubarak government in Egypt - all of them part of a generically labeled "Arab Spring" movement of popular uprisings in North Africa and the Middle East. These movements had found a symbol in a Tunisian fruit vendor who martyred himself by self-immolation and whose act had been captured and diffused widely in the region.

Following these developments, there was a move in the United Nations not only to condemn the use of violence against Syrian civilians, but also to invoke R2P - an act invoked in the Libyan crisis which was not vetoed in the UN Security Council and was implemented, following France's lead, with collaboration of NATO arms, personnel, and coordination.

While looking at this issue, there are many opportunities for discursively analyzing how the events and actors are contextually presented at various levels of discourse and over differing time frames, for instance "clock time" versus "calendar time" (MIHELJ, 2011). These broader discursively important aspects of analysis remain outside the scope of this limited project, though they would be key in helping to broaden the understanding of policy formation and implementation, forcing deeply normative questions regarding policy justification and rationalization and the role of media into a more central position in such a work.

The focus in this short study, however, is to look at how an outwardly-oriented and foreign audience-focused English-language news media, via its opinion pieces, constructed the R2P and Sovereignty discourse.

In particular, this research defines strict parameters regarding those two discourses and analyzes a discourse over the concept of R2P versus the challenging discourse of Sovereignty in the case of the Syrian conflict and as represented and distributed by two specific media outlets with significant or dominant audience share in their intended markets.

In the case of Syria, which remains in conflict to this date, the Security Council in 2012 twice went to a vote in an attempt to acknowledge the conditions allowing for the invocation of R2P and the consequent right to "use all necessary means" in order to address the humanitarian concerns in that conflict, including the violence against 
civilian populations by the state political leadership and military forces.

Of the five permanent members in the UN Security Council - who can individually veto any UN Resolution brought before them - two of them, China, along with Russia, voted both times against the invocation of R2P. China and Russia vetoed the UN Resolution on both 4 February 2012 and 19 July 2012. The United States, along with France and Britain, voted in favor of it and its invocation of R2P.

My study looks at newspaper opinion pieces from the Englishlanguage China Daily and compares them to the opinion pieces of The Washington Post during a short period when both China and the United States were advocating opposing policy actions publicly and at the United Nations in 2012.

\section{METHODS}

The research was conducted by reverting to a LexisNexis and newspaper website text-based search for "Syria" with the additional specific phrases of "Responsibility to Protect" and "Sovereignty" to include other related words, such as "obligation" and "intervention" specifically regarding the Syrian crisis. The search dates of the research were limited to the short period both prior to and following both UN Security Council votes: from 4 February 2012 to 9 February 201

The total number of opinion pieces reviewed amounted to the following:

The China Daily: 25 out of $77^{1}$ articles reviewed.

The Washington Post: a total of 16.

The applied method of analysis is Critical Discourse Analysis (CDA), reviewing the use of news article excerpts from the two newspapers with both language and context analyzed in two time frames: 1) During and after the first UN vote, 2) Immediately before, during, and after the second UN vote.

In constructing the framework for this comparative analysis of the two newspapers, this project relied on some of the methodologies employed by Michael Chan (2012) ${ }^{2}$ and the work of Li Juan ${ }^{3}$ in the journal Discourse \& Society (2009). Both Chan and Li look specifically at case studies of China and the United States and use similar comparative methodologies, with Chan specifically using the Beijingbased China Daily and Japanese Daily Yomiuri in his study of the discursive reproduction of ideologies and national identities. 
Also key to the methodological approach of this research is some of the work written by or edited by T. A. van Dijk (1985). Of particular interest in shaping the analysis is van Dijk's focus on moving much of the media analysis surrounding issue of policy from a dominant academic tradition focused on content analysis to the broadening stance of expansion into the more interpretively recognized realm of discourse analysis. Prior to a reading of van Dijk, one of the foci of this study was to rely heavily upon content analysis (i.e., using the number of times that "Responsibility to Protect" or "Sovereignty" appear in the respective newspapers). Instead of being a central aspect of this project's analysis, it became a search parameter in order to define the conceptual boundaries of that which is analyzed.

Finally, the coding approach to the qualitative data and the interpretive direction taken was guided by the logic outlined in the second chapter of the book by Coffey and Atkinson (1996). The explanatory principles for coding accompany the data analysis in the following sections.

\section{OVERVIEW OF DATA BODY}

First, a quick look at the pieces that are covered in this study and how they are broken down. Opinion pieces in both newspapers are generally of the same length, around 400-700 words on average, and all are focused on the Syrian issue and most refer to the UN vote (either upcoming or just taken).

The opinion pieces that are bylined in China Daily are mostly from Chinese academics that work at Chinese think tanks, though there is one piece penned by a Russian foreign policy academic. Most of the American pieces are also written by a foreign policy elite, but with some of the contributors coming from farther afield than the American academy.

What follows is the breakdown of the reviewed data set:

Table 1 Number of Opinion Pieces

\begin{tabular}{|l|l|l|}
\hline & Number of Opinion Pieces & Number of Opinion Pieces \\
\hline & First UN Vote & Second UN Vote \\
\hline $\begin{array}{l}\text { China Daily } \\
\text { Washington }\end{array}$ & 7 total out 33 & 12 out of 44 \\
\hline Post & 9 total \\
\hline
\end{tabular}

Source: elaborated by author 
Coding for this category of opinion pieces required deciding on articles that were not listed as Opinion pieces in the China Daily, but which carried opinion oriented headlines or content that was minimally reported and which mostly reflected a strong opinion or editorial position supported mainly by author argument.

While many of the China Daily pieces were self-identified as Opinion or Editorial pieces, it was necessary to dig into news articles themselves, too, to decide whether to place them as opinion pieces or not. Of the 25 total China Daily pieces coded as Opinion pieces, only 10 of them were self-identified as such by the newspaper. Pieces that were not self-identified were strongly worded or lightly reported and included headlines such as "Why Another UN Draft Resolution Vetoed" were coded as Opinion. Other articles, such as "Syria Completes Drafting Constitution" were not coded as Opinion. China Daily pieces that were self-identified in the Opinion-Editorial pages followed the international convention of attaching a byline to pieces written as non-staff opinion and without byline if they were staff editorials.

Pieces for The Washington Post were all either bylined Opinion pieces or non-bylined staff Editorial pieces. The articles in the news section of the newspaper were reviewed to see if the coding on the articles should also be changed to Opinion, but The Washington Post articles adhered to the stricter convention of heavily reported pieces in the news "well" of the newspaper and, thus, not being recoded as opinion for this data set.

Once the data set was defined and the opinion pieces extracted, read, and coded as Opinion, the second stage of the discursive analysis involved categorization of the respective framing of the two policy concepts and how they are constructed. This was the more demanding of the tasks and required an even higher level of qualitative interpretation and a CDA approach.

As discussed earlier in this paper, some of the value framing of the policy principles of R2P and Sovereignty overlap as categories, in particular when it comes to the Legal framing of the argument. As noted in the chart that follows, for example, both R2P and Sovereignty use Legal framing for their arguments for discursively advocating for one or the other principle.

In Legal framing, The Washington Post opinion pieces (with one exception ${ }^{4}$ ) apply R2P media advocacy to invoke two specific codifications, the UN's Universal Declaration of Human Rights and the UN's 2001 R2P vote. The pieces either suggest or outright say that R2P overrides Sovereignty concerns. 
The opinion pieces in China Daily all come down on the side of the Legal argument for Sovereignty and refer to the founding charter of the United Nations, but also go back as far as the Peace of Westphalia. The opinion pieces also refer to hundreds of years of legal precedent, such as the concepts from various articles calling for "non-interference" and "equality" in their discursively constructed advocacy for the principle of Sovereignty.

A further look at the coding scheme follows:

Table 2 Sovereignty and R2P concepts

\begin{tabular}{|l|l|}
\hline China Daily & Washington Post \\
\hline Sovereignty & \\
\hline Legal x & R2P \\
\hline Historical x & Legal x \\
\hline Regime Change - External & Revolution - Internal \\
\hline More Bloodshed & More Bloodshed \\
\hline Domino Theory & Domino Theory \\
\hline Legitimization of State & Legitimization of Action \\
\hline Othering ("the West") & Othering (China \& Russia) \\
\hline Titling (President Assad) & Dehumanizing (Assad \& Junta) \\
\hline Independent Choices & Irrationality \\
\hline Imperial Designs & Vital National Interests x \\
\hline Near Silence on “R2P" & Near Silence on “Sovereignty" \\
\hline State's Rights x & Human Rights x \\
\hline Regional Destabilization & Regional Security \\
\hline
\end{tabular}

Source: elaborated by author

Value Coding $(\mathrm{x})$ and Framing Coding for the Opinion articles in both the Washington Post and the China Daily.

The value coding and framing coding of the discourse is binary, with China Daily creating an advocacy discourse on the side of Sovereignty exclusively and The Washington Post, with one exception, creating an advocacy discourse for R2P.

The discourse created in the text of the opinion pieces was coded into general principles and policies that are advocated and those principles and policies are then broken down into their constituent elements, as will here be synthesized: 
Historical precedent is used by both principles in most articles as a justification for the advocated preference. Sovereignty discourse used history as a warning, as when one Chinese author argued that R2P actions by the US in the past have brought "deaths, destitution, and humanitarian crises."

Not only have the two camps found a series of reinforcing arguments to support their discourse, but they also use silence to advocate for their preferred policy and principle. In the case of Sovereignty advocacy, China Daily pieces keep silent as to the validity or precedent of the R2P principle; the opposite is also true for the R2P pieces, though a few of the pieces acknowledge the competing legal principle.

The framing of the discourse and the categorization allows for a means by which to order both measured and vitriolic rhetoric under the coded rubrics; what is not measured as the categories are defined is any intensity or extremity in the use of language, though this is a natural consequence of any coding scheme that aims to reduce complexity. What is lost in this exercise is the ability to identify phrases such as "cold blooded massacres" and "slide into anarchy" that are used by the R2P camp in the media and instead fall under the rubric of "More Bloodshed"; the Sovereign media camp falls under the same category when it refers to "the cruel reality in Iraq is enough to shatter the premise of unwarranted outside intervention."

Domino theory covers both as well. R2P pieces argue for stopping the Syrian crisis via intervention because "only then will murderous dictators think twice" while multiple Sovereignty pieces bring up the question raised by one author of "what Arab country will be next?" The Domino Theory argues that what happens in this instance will only be the first in a series of consequent and similar events over time.

The remaining categories, too, are fixed in their binary coded analytical framework: Where The Washington Post pieces Dehumanize the Syrian leadership by referring to them as a "junta" and "murderous dictators" or the head of state as just plain "Assad," the China Daily pieces confer legitimacy on the leadership by referring to their actions as "Syrian independent choices" and giving the head of state his given title of "President Assad."

The replication of extreme discursive positions is what characterizes this analysis with, as previously noted, one exception in The Washington Post: An opinion piece by the former US Secretary of State, Henry A. Kissinger. Because of the status of the author and his history as a scholar and practitioner of the realist school 
of international relations, his piece carries greater weight in the advocacy of principle and policy schema.

Kissinger writes in opposition to intervention on realist grounds - that the United States cannot do everything, intervene everywhere, and police everyone - regardless of the real humanitarian crises and justice or injustice being done. He acknowledges the conditions, but separates any moral obligation or legal requirement for intervention based on R2P, making a specific claim that there is a difference between humanitarian and strategic intervention - a claim directly unacknowledged in any of the other opinion pieces of either newspaper. Critical of all the other approaches in the opinion pieces in The Washington Post, this outlier from the general framework and schema in the previous Figure presents a more complex and not entirely unified construction for how the newspaper frames and advocates for a policy or principle of R2P.

It may be that this dissent from the remaining unified voices creates an understanding that the opinions in The Washington Post are pluralistic and, therefore, lend credence to the majority of voices and otherwise unity of voice advocating for R2P. Regardless, it is notable in that China Daily's opinion pieces are entirely unified in their constructions and advocacies of Sovereignty.

The Opinion pieces in both newspapers have created a multilayered and complex construction of the two policy principles and have, further, created a scheme by which they advocate for those principles. They are not limited in their advocacy of the principles themselves, however, but also extend their advocacy - in plain terms - for policy action. The following Figure outlines the axes of Principle Advocacy and Policy Advocacy by the two newspapers drawn from the same data set outlined previously:

Table 3 Principle Advocacy x Policy Advocacy

\begin{tabular}{|l|l|l|}
\hline $\begin{array}{l}\text { Media Policy } \\
\text { Advocacy (below) }\end{array}$ & $\begin{array}{l}\text { Washington Post } \\
\text { \& R2P Principle } \\
\text { Advocacy }\end{array}$ & $\begin{array}{l}\text { China Daily \& } \\
\text { Sovereignty Principle } \\
\text { Advocacy }\end{array}$ \\
\hline Non-Intervention & & X \\
\hline Negotiation & $\mathrm{X}$ & $\mathrm{X}$ \\
\hline $\begin{array}{l}\text { Humanitarian or } \\
\text { Military Aid }\end{array}$ & $\mathrm{X}$ & \\
\hline Intervention & $\mathrm{X}$ & \\
\hline
\end{tabular}

Source: elaborated by author 
Data from the opinion pages of the two newspapers coded and framed regarding their principle or policy advocacy.

The only area of advocacy overlap between the two newspapers is in the area of negotiation, regardless of who the brokering party is in this case. The studied media advocates of $\mathrm{R} 2 \mathrm{P}$ also advocate a much more robust set of actions than do the media advocates of sovereignty, who call for a more passive and noninterventionist response.

The preferred policy coding is non-interpretive and extracts from the data set direct calls for either intervention or nonintervention and plots it against the already established alignment of the respective newspapers and their preferred principle advocacy. Direct representation of intervention is a straightforward definitional use of words within the Opinion pieces that, in The Washington Post pieces, are expressed as "arm the resistance" or "the Assad killing machine must be stopped" or "the longer (Obama) waits, the greater the cost - in children's lives, among other things."

In the case of the China Daily, direct calls for non-intervention are found in phrasing such as "Only Syrians have the right to decide Syria's future," or calling directly for "non-interference."

\section{FINDINGS}

Media construction of the R2P and Sovereignty concepts adhered to multiple discursive approaches for legitimizing and supporting the legally and historically defined principles. As made explicit in the Data Body review, the two newspaper's opinion pieces hewed nearly perfectly to the one concept or the other. The China Daily stuck perfectly to its construction of a multilayered understanding of the Sovereignty principle in the Syrian crisis and, further, in its advocacy both for the Sovereignty principle and for a sovereignty-based non-intervention policy. The Washington Post, too, clung closely to its construct of R2P and advocated both for a strong $\mathrm{R} 2 \mathrm{P}$ principle and for a more interventionist-oriented policy (with the previously noted exception of the piece by Henry A. Kissinger).

One of the expectations at the outset of this study was that the newspapers from China and the US might align to some degree with their host nation's policy regarding the two principles studied.

The following figure shows a simple analysis of the Data 
Body for this paper where the structure of the national media organization is juxtaposed against the policy alignment with the media organization's host nation.

Table 4 Policy alignment with the media organization's host nation

\begin{tabular}{|l|l|l|l|}
\hline & Independent & State Owned & Policy Alignment \\
\hline China Daily & & $\mathrm{x}$ & $\mathrm{x}$ \\
\hline Wash. Post & $\mathrm{x}$ & & $\mathrm{x}$ \\
\hline
\end{tabular}

Source: elaborated by author

Though the media outlets are structurally very different, with the China Daily a part of the state structure and directly responsive to state hierarchy and The Washington Post an independent, publicly listed shareholder entity, their alignment (with previously noted exception) with state policy is nearly indistinguishable. The Chinese publication had a perfect alignment with state policy and the American publication was near perfect.

A finding drawn in this paper is that major national Englishlanguage newspapers in the construction and advocacy of the two studied principles in the case of the Syria crisis, reflect the early and established foreign policy positions of the host (and allied) state(s) in their editorial content. The finding is that the constructed discourse in The Washington Post newspaper reflects, adapts, and promotes the national narrative and policy position - perhaps with greater vehemence - contra to the contradictory narrative constructed by the China Daily, a news institution of the other, non-allied state.

It is understood that there is some amount of room for agenda setting' by the newspaper editorial organizations. A deeper finding along this line would require further work outside the scope of this project and would necessitate a separate study in order to determine the level of independence/dependence that The Washington Post has from the US government versus the China Daily and its respective sponsor government - the Chinese newspaper's owner.

Given the institutional authority and dominant position as China's only national English-language newspaper, China Daily was found, via a genre analysis related to Martin's varietal approach to Systemic Functional Linguistics ${ }^{5}$, to be reproductive of the values and narratives of the state in "monoglossic" fashion, or, in a singular and aligned state voice. ${ }^{2}$

Theories that adduce to a monopolistic, state-owned press are not as relevant, however, when the contrasting object of analysis is a market- 
based news organization with loose ties to state authority, though there may be elite affinity and agenda sharing proclivities. Reproducing state foreign policy perspectives is neither automatic nor coercively induced in the case of The Washington Post, though the more critical the policy is to engaging responsive military resources, the closer the alignment and reproduction of the state policy (ROBINSON, 2001). The theory that a media organization's power to change state policy as an independent actor, with independent non-state aligned agendas in times of crisis have been mostly disconfirmed, though the term "CNN Effect" has influenced a popular sense of an independently impactful relationship between news organization and state foreign policies (GILBOA, 2005). ${ }^{6}$

While the general alignment with state policy preferences by these two newspapers was established from the research and the data body, a wider finding was that the language used - and the intensity of the language used - in these media tended to be more forceful than the typical diplomatic language used by official representatives of the state. The discourse constructed within the media trended towards the more vitriolic, belligerent, and extreme.

\section{CONCLUSION}

There are four specific conclusions that can be drawn from the research for this paper and they will be put in as generalizable a form as allowable given the narrow and snapshot nature of this study.

First, media in this study and via their opinion pieces during the researched period did construct a multilayered and complex narrative discourse surrounding the two principles of R2P and Sovereignty.

Second, the researched media advocated for the principles and the policies they constructed as their preferred ones.

Third, these very same media were found to align their constructed discourse near perfectly with that of the host nation's policy preferences.

And, fourth, finally, and unexpectedly, the studied media were further found to use more extreme language in the construction of and advocacy for the principles and the policies of R2P and Sovereignty than the constructions used by the respective media's host nations. While the original intent of the study was not aimed at researching or measuring this phenomenon, this conclusion was an outgrowth of the coding process and framing analysis of the collected data. 
A further study into this final point might show, as this researcher would now expect, that the media do not adhere to the rules or principles of diplomacy; they are neither responsible nor accountable for their rhetoric to the same degree that governments are, and what this short study seems to indicate is that the discourse is much more bellicose, confrontational, and extreme in its polar position than that which emanates from the state and its representatives.

Relatedly, and as seems initially borne out of the research for this paper, the direct relationship of state to state-media, as in the case of China Daily, while more extreme than official state pronouncements, may actually be more a moderated discourse than that which comes from an independent news source which may be aligned, but not accountable to its host nation.

The topic of media discourse in foreign policy has relevance both to policymakers today in the respective capitals of Beijing and Washington, DC, in that a dominant and overriding internationally accepted concept will have important implications for the execution of policy, humanitarian action, military intervention, and issues regarding the rights of minority populations and autonomous regions within sovereign states.

If the evolving global state media networks are, as this scholar's early research appears to be indicating strongly, in near perfect alignment with their state sponsors to the extent that their reporting networks can be seen as extensions of foreign ministries, then it is important to understand how and why the discourse that is being produced by these bodies take the shape they do and what role they play in the international policy formation and advocacy realm.

\section{Notes}

1 Besova and Cooley, "Foreign News and Public Opinion: Attribute Agenda-Setting Theory Revisited."

2 Liu Lihua, "Formalizing Power in Editorials in China Daily: A Genre Analysis."

3 The reason for the discrepancy between the number of articles reviewed and coded as Opinion is visited in the Data Body Review section of this paper. 
4 This is the work that was recently reviewed for Assignment 1 for the Discourse Analysis class Winter 2013.

5 Li looks at the cross-cultural differences between the relationships of individuals and their national identities in the social media space. Aspects of this study lend insight into the evolving understanding of competing national identities and their relationship to media.

6 An opinion piece by Henry A. Kissinger.

7 In this analysis, Martin makes the common Systemic Functional Linguistic analysis that "social context and language metaredound." That is, social context impacts language that then defines, reflects, and/or changes the social context over time. This is important in the study of how the editorial policy and language of China Daily relate to the foreign policies of the People's Republic of China.

8 The exception to the general finding of no independent media effect is in cases where policy direction by the state in cases of humanitarian intervention are generally ambiguous and undecided by the state and where the costs of intervention are considered balanced by the costs of non-intervention. In clear cases where policy has been decided, the default action of the state will both be the policy and the reproduced discourse by the news organization - in particular, once the policy direction is implemented.

\section{References}

BESOVA, Asya A.; COOLEY, Skye Chance. Foreign news and public opinion: attribute agenda-setting theory revisited. Ecquid Novi: African Journalism Studies, v. 30, n. 2, p. 219-242, 2009. Disponível em: <doi:1 0.1080/02560054.2009.9653403>. Acesso em: 31 dez 2014.

CHAN, Michael. The discursive reproduction of ideologies and national identities in the Chinese and Japanese english-language press. Discourse \& Communication, v. 6, n. 4, p. 361-378, nov. 1, 2012. Disponível em: <doi:10.1177/1750481312457496>. Acesso em: 31 dez 2014.

CHRISTIE, Frances; MARTIN, J. R. Martin. Genre and institutions: social processes in the workplace and school. London: Continuum International Publishing Group, 2000.

COFFEY, Amanda; ATKINSON, Paul. Making sense of qualitative data: complementary research strategies. New York: SAGE, 1996.

DIJK, Teun A. van. Discourse and communication: new approaches to 
the analysis of mass media discourse and communication. Berlin: Walter de Gruyter, 1985.

EVANS, Gareth; SAHNOUN, Mohamed. The responsibility to protect. Foreign Affairs. v.81, no. 6, p.99, 2002. Disponível em: <doi:10.2307/20033347>. Acesso em: 31 dez. 2014

GILBOA, Eytan. Global television news and foreign policy: debating the CNN effect. International Studies Perspectives v. 6, n. 3, p.325-341, 2005. Disponível em: <doi:10.1111/j.1528-3577.2005.00211.x> Acesso em: 31 dez.2014.

GROTIUS, Hugo. Hugonis Grotii De jure belli ac pacis libri tres. s/l: sumptibus Marcus-Michaelis Bousquet \& sociorum, 1751.

LI, Juan. Intertextuality and national identity: discourse of national conflicts in daily newspapers in the United States and China. Discourse \& Society, v. 20, n. 1, p.85-121 ! jan. 2009. Disponível em: <doi:10.1177/0957926508097096> Acesso em: 31 dez. 2014 ..

LIU Lihua, Formalizing power in editorials in China daily: a genre analysis. Linguistics \& the Human Sciences, v. 5, n. 2, p.195, ago. 2009.

MIHELI, Sabina. Media nations: communicating belonging and exclusion in the modern world. Basingstoke: Palgrave Macmillan, 2011.

ROBINSON, Piers. Theorizing the influence of media on world politics models of media influence on foreign policy. European Journal of Communication, v. 16, n. 4 (December 1, 2001): 523-544. doi:10.117 7/0267323101016004005.

WOOD, B. Danl PEAKE, Jeffrey S. The dynamics of foreign policy agenda setting. The American Political Science Review, v. 92, n. 1, p. 173184, 1 mar. 1998.

Marcos Kounalakis is visiting Fellow at Hoover Institution, Center for Media, Data and Society, Stanford University. E-mail: kounalakis@gmail.com. 